\title{
The Study of Two International (Regional) Systems before and after the Greco-Persian Wars
}

\author{
Ming Guo ${ }^{\mathrm{a}}$ \\ Macau University of Science and Technology, 999078, Macau \\ Guangdong Institute of Science and Technology, Zhuhai, 519000, China \\ aguodream@163.com
}

\begin{abstract}
The Greek wave of 499 BC to 449 BC was a series of wars and conflicts that erupted between the ancient Greek city and the eastern Persian. Through the analysis and combing of the reasons for the Greco-Persian war, try to dig out the city, and the eastern Persian Greek two area (International) power system, different form system and culture, in order to more clearly show that before and after the Greco-Persian war, ancient Greece and Eastern Persian International (regional) some of the attributes of the system provide benefits for better understanding, fifth Century - fourth Century BC the eastern and western regions.
\end{abstract}

Keywords: the Greco-Persian Wars, International (regional) systems.

\section{Introduction}

The fifth century BC, Greece and Persia as the two most typical civilization on the Mediterranean, has been aroused the interest of academia and people. The conflict and communication between them not only have a profound impact on the historical development of each other, but also affect the development of the world history and regional trends. The rise of the Persian nation in the Iranian plateau is a branch of the Indo-European tribe of the Aryanian tribe, which first lived on the prairies of the Eurasian continent and the Aral Sea to the south, and then moved southward to the Mesopotamian plain North. In 559 BC, Cyrus II (Cyrus the Great) boarded the Persian throne, established the Achaemenid Empire. In the ten year of his reign, conquering Lydia (549 BC), Babylon (539 BC), Egypt (525 BC) to create a 200 year history of the three continents across Africa and Europe relatively centralized empire. From 522 BC to the first 486 years, after the war and expansion, Darius expanded the territory of the Persian Empire from northern India to Turkey, including Egypt, the territory of the world's largest Kingdom. BC 492 years ago to 449 years of Persia to Greece launched lasted 50 years of war. The war ended with the failure of Persia, but Persia had been reluctant, and in the following 50 years, the Persian had the opportunity to intervene in the struggle of the various cities within Greece. Until 334 BC, the Macedonian Alexandria, exterminate Persia. Therefore, the Greek Persian up to two centuries of disputes before the end.

The international system as a special international public goods, independent international actors, after a long period of interaction to form a relatively stable relationship structure, international order, change patterns and patterns. According to the definition of Boolean and Watson, the international system refers to the fact that there is sufficient connection between two or more countries and that they have sufficient influence on each other's decisions and that they are integrated as an international system. The following analysis of the two international (regional) system in the behavior of the anarchy, structural characteristics, interactive way to explore the classical era of ancient Greek city and Persian that inextricably linked.

\section{An Analysis of the Behavior in the Two Systems in the Greco-Persian war (Empire and City)}

\subsection{State form: Empire and city}

After 522 BC to 486 years of war and expansion, Darius conquered Babylon, Egypt, northern India and other regions, became the world's largest empire. In order to rule such a large empire, the ancient 
Greek historian Xenophon, in his "Cyrus education" book lists the Persian king rule the empire of the various methods: to create a provincial system, sent the governor; levy taxes and coin system; the local implementation of military rule, designated military commanders; raising all kinds of cronies with the eyes and ears, supervision officials and subjects; the establishment of beacon system, built by message.

Then, the Persian Empire ruled the country, is a across the Indus, the Danube, the Nile and the Eurasian continent, and the various regional traditions, economic and religious culture has a huge difference between the great empire. In order to strengthen the control of the place, the king set up the province, let the governors supervise each other, carry out the infrastructure construction, build the post road, and let the news convey more efficient. And even strengthen the construction of intelligence systems, supervise local officials and locals. When the local governor appears disobedient and rebel signs, the king will take the brutal, bloody measures to be suppressed or executed.

Around 8 Century BC, with the development of commercial trade, the Greeks emigrated abroad. In the Greek mainland, the northern part of the Aegean Sea, Bosphorus across the strait, the furthest reaches of the Black Sea coast, southeastern France and the eastern part of Spain, the establishment of hundreds of new city. These city-states, like today's clubs and clubs, have their own preferences, and the typical city-states are exclusive. Foreigners are not allowed to marry with the citizens of the city, are not allowed to own the land, are not allowed to participate in religious rituals. In addition, each city has its own goddess or goddess as protector, such as Hera guarding the city of Agos, Apollo guarding Apollonia, Assina guarding Athens. The pattern of early liberalization of the Greek city-state became the basic state of the Greek world.

As the Greek city-state respect for the autonomy of the city-state principle, long-term separation, it did not form a unified country. Because of the dispute between the city and the country because of the resources or the geopolitical relations, the cities that contain each other and even oppose each other cannot deal with the geopolitical invasion of the Persian unified regime. The principle of autonomy of Greek polis leads to lack of coordination, unstable alliance and dominate the struggle. As the Persian war, Athens, Corinth, Sparta, Thebes has become the city-state's overlord, and Persia in the Greek city of internal hegemony in Greece in battle, and even provoke City infighting and reap the benefit. However, the independence of the city-state system and the containment of Persian foreign policy make the Greek city-state gradually decline.

\subsection{The political system: monarchy and democracy and the rule of law}

The Persian Empire conquered the vast territory of the Middle East economic development is not balanced, and some areas are still under the clan system, engaged in wild fruit collection and hunting nomadic life. In order to obtain the conquest of the surrender, Cyrus and Gombe are in accordance with local customs and habits of the Sith, giving the conquest of the various ethnic groups in the local autonomy and appropriate. And the characteristics of cooperative monarchy and local autonomy in the rule of the Persian Empire, the Persian Empire is fundamental to the cause of long-term maintenance.

The Greek city of democracy and rule of law once became the most prosperous area of the Greek peninsula. As early as the fifth century BC, democracy, civil liberties, political freedom in the Greek city-state popular. In the era of Belize, ancient Greece has a fairly complete civil council, council, jury court and other political organs. Freedom of citizens to participate in political power is guaranteed, and the idea of fighting for freedom has become a classic saying of morale. In 490 BC, when Persia attacked the city of Athens, the commander of the Greek commander, in order to let the soldiers fight the enemy, said: "Now, or let the chain of slaves added to the Athenians, or keep the Athenians The freedom is tied to your hand! "

As a result of the Greek city-state gradually weakened, Aristotle and a group of philosophers are thinking about a question: democracy and urban governance and city-state disputes have a relationship? Aristotle then visited the Greek city-state in 158 and visited, wrote "politics" famous book, the Greek government is divided into oligarchy, democracy, hybrid regime, tyranny (dictatorship) and other six kinds of forms. Since the Persian war, the Greek city-state in the Peloponnesian War and Greek era melee. The war not only caused serious damage, resulting in more Greek political crisis. As at the time the highest civilian government citizen conference or useless arguing, the city state of democracy in the 
war has become vulnerable. "Athens ten the general provisions of the supreme commander of the war" by election, and turns the power".

\section{The Interaction of the Two Systems in the Greco-Persian War (War and Conflict)}

From the historical practice analysis, war and conflict basically constitute the basic characteristics of the Persian Empire and the ancient Greek international system. Realistic theory tells that the instability within the international system and the anarchy and the "security dilemma" that have arisen in the system have led to the outbreak of war and ongoing conflict between Persia and ancient Greece for the realization of power and its own security interests.

\subsection{Power Interaction: Hegemony}

The war and the alliance is the main way of supremacy of Pes Bos and the ancient Greek region, war is the direct driving force system of power distribution and promote the transformation of the international system. As the rapid growth of national strength and to seek national interests, its strong will break the balance of the power system in the state. While the victim in the "security dilemma" logic next, must feel the threat to national security, will not want to be oppressed by hegemony, so the alliance means to compete for dominance in the system, before and after the Persian war, the Persian and Greek conflict can be learned.

The Persian Empire wanted to dominate the Mediterranean. Darius during the conquest of the Aegean Sea on the north shore of the Greek city of Thrace, the Greek state of the mainland feel the security threat, so to help the small sub-Greek city-state anti-Persian invasion. The outbreak of $490 \mathrm{BC}$ to $480 \mathrm{BC}$ four times a large front of the war. In the face of Persian war, the Greek system within the city united front, and even Greece and Sparta to abandon the hatchet, common enemy. Then the Salamis Bay naval victory, Athens city has gradually become the system. A new force suddenly rises., the ancient Greek city-state formed with Athens as the center of the Delian League, and centered on Sparta in the Peloponnesian League of the civil war, the foreign policy is to curb Athens's control. When Sparta became more and more powerful under the support of Persia, Persia took the policy of taking turns to restrain, which supported the anti Sparta alliance, which led to the collapse of several major Greek cities.

It is clear that Greece, Athens and Sparta have the will to dominate the Mediterranean. The balance of power in the Greek city states and the balance of power between Greece and Persia were broken, which eventually led to the development of the highly developed countries of the Greek city of slavery eventually weakened. As the waltz argues, "in the absence of government order, the main unit on the basis of the implementation of similar task ability size to distinguish changes in capacity allocation (or power transfer) is an important factor in changing system"

\subsection{Cultural Interaction: Ideological Controversy}

In the Greek city and the Persian international system, the evolution of the international system is influenced by the national conditions, the unique concept of the border and the way of life, not only the power of the countries such as Sparta, Athens and Persia. Persia believes that Asia and all the aliens living on this land should be subordinate to their own, want to Asia Minor Greek city city for their own, leading to its contradiction with the small Asian city. Darius to continuously strengthen the military dictatorship and respect Zoroastrianism, with force and religion 'a hard one soft' two ways to maintain the rule of the empire. On the one hand the use of coercive means to suppress the local forces of the anti-Persian uprising, on the other hand through the promotion of religion, instilling the idea of abandoning evil from the uprising of the region.

In the history of the Greek city states, although the United States did not form a unified situation, but most of the city-state is politically independent. In the Greco-Persian war, although some of the city-state was invaded and controlled by the hegemonic war, there was little evidence of annexation. Hornblower was on the relationship between the Greeks in Asia Minor and Persia made in-depth analysis, pointed out that the love of freedom that they continue to revolt against the Persians, the Persian sides in the ideological differences between them is contradictory is an important factor. Even 
in the later Peloponnesian war, the ancient Greek world fell into the struggle between the Democratic Party (the Athens League) and the noble party (Spartan League) representing the interests of the landlords, representing the interests of the industrial and commercial slave owners, Of the city has never really abandoned their independence.

\section{Summary}

Ancient Greece and Persia were once in the history of the two regions, but the war and the conflict as the devil has always been accompanied by the development of two regions. By analyzing the changes of the international system of ancient Greece and Persia around the Hibo war, we use the three dimensions of power, system and culture to find out the differences of the two different international systems. The Greek city-state war with Persia in addition to the intricate interests of the request, but also with the complex historical, geographical, cultural and other factors related. For example, Spartan has a strong land of the armed forces at the time, but because of the lack of funds plaque, farming mainly, so the naval power is weak; Athens use its advantages of geographical location, enlightened political democracy and development strategy, the establishment of a classical world First-class navy. Therefore, Persia and Athens and Sparta compared to its military power is not strong, but it is a resource-rich, vast region of the empire, with strong financial and flexible diplomacy. So in the Mediterranean of the origin of this European civilization, interpretation of a swaying Hiroshi wave of international system development history.

\section{References}

[1]. Ma Jing. Comment on the three major theoretical schools of international relations on the understanding of the international system. Academic aspect, Vol. 5(2010), p.73.

[2]. Xenophon. Cyrus Education, Beijing: Huaxia press, 2007, p.408 - 471.

[3]. Jin Yan. Autonomous City and Geographical Dilemma - Analysis of the Reasons for the Decline of Greek City. Journal of Longdong University, Vol.24(2013)No.2,p.118-120.

[4] Li Yi. From the perspective of ancient Greek democratic politics analysis of Greece in the Greco-Persian war victory reasons. Theorists,(2008)No.1p.109-110.

[5]. Village Fu: "Ancient Greek masterpiece", Zhejiang: Zhejiang People's Publishing House, 1989, p.133.

[6]. Waltz, Xin Qiang. International Political Theory. Shanghai People's Publishing House.2008, p.103.

[7]. Simon Hornblower. The Greek World 479-323BC.London and New York, 1983. 